\title{
Cytotoxic and antimigratory effects of Cratoxy formosum extract against HepG2 liver cancer cells
}

\author{
BENJAPORN BURANRAT ${ }^{1}$, NOOTCHANAT MAIRUAE ${ }^{1}$ and WATCHARA KANCHANARACH ${ }^{2}$ \\ ${ }^{1}$ Faculty of Medicine, Mahasarakham University, Muang, Maha Sarakham 44000; ${ }^{2}$ Microbiology and Applied Microbiology \\ Research Unit, Department of Biology, Faculty of Science, Mahasarakham University, Maha Sarakham 44150, Thailand
}

Received November 8, 2016; Accepted February 20, 2017

DOI: $10.3892 /$ br.2017.871

\begin{abstract}
The aim of the present study was to investigate the molecular mechanisms underlying Cratoxylum formosum (CF) Dyer-induced cancer cell death and antimigratory effects in HepG2 liver cancer cells. The cytotoxic, antiproliferative and antimigratory effects of CF leaf extract on human liver cancer HepG2 cell lines were evaluated using sulforhodamine B, colony formation, and wound healing assays. In addition, apoptosis induction mechanisms were investigated via reactive oxygen species (ROS) formation, caspase 3 activities, and mitochondrial membrane potential $(\Delta \Psi \mathrm{m})$ disruption. Gene expression and apoptosis-associated protein levels were measured by reverse transcription-quantitative polymerase chain reaction and western blotting. CF induced HepG 2 cell death in a time- and dose-dependent manner with half maximal inhibitory concentration values of $219.03 \pm 9.96$ and $124.90 \pm 6.86 \mu \mathrm{g} / \mathrm{ml}$ at 24 and $48 \mathrm{~h}$, respectively. Treatment with CF caused a significant and dose-dependent decrease in colony forming ability and cell migration. Furthermore, the present study demonstrated that CF induced ROS formation, increased caspase 3 activities, decreased the $\Delta \Psi \mathrm{m}$, and caused HepG2 apoptosis. CF marginally decreased the expression level of the cell cycle regulatory protein, ras-related C3 botulinum toxin substrate 1 (rho family, small GTP binding protein Rac1) and the downstream protein, cyclin dependent kinase 6 . Additionally, CF significantly enhanced p21 levels, reduced cyclin D1 protein levels and triggered cancer cell death. CF leaf extracts induced cell death, stimulated apoptosis and
\end{abstract}

Correspondence to: Dr Benjaporn Buranrat, Faculty of Medicine, Mahasarakham University, 296 Nakhornsawan Road, Muang, Maha Sarakham 44000, Thailand

E-mail: buranrat@gmail.com

Abbreviations: CF, Cratoxy formosum; CDK6, cyclin dependent kinase 6; MMP-9, matrix metalloproteinase-9; $\Delta \Psi \mathrm{m}$, mitochondrial membrane potential; $\mathrm{RAC1}$, ras-related $\mathrm{C} 3$ botulinum toxin substrate 1 (rho family, small GTP binding protein Rac1)

Key words: Cratoxy formosum, cytotoxicity, HepG2, liver cancer, migration inhibited migration in HepG2 cells. Thus, CF may be useful for developing an anticancer drug candidate for the treatment of liver cancer.

\section{Introduction}

Medicinal plants and their active compounds have been reported to exert potent cytotoxic activity against various types of cancer cell (1). Numerous plants are consumed as food and are claimed by practitioners of traditional medicine to promote health (2-4). Northeast Thai vegetables, such as Cratoxylum formosum (CF) Dyer may have an affect on human health by exerting antioxidant and anticancer effects. CF belongs to the Guttiferae family and is a plant of the tropics, cultivated in many Southeast Asian countries, including Thailand (5). It is a local dietary and herbal plant, and its leaves are usually consumed fresh. CF has been adopted in folk medicine for the treatment of fever, coughs, stomach ache and peptic ulcers $(6,7)$. CF produces various secondary metabolites, including phenolic compounds, triterpenoids, flavonoids $(6,8)$, xanthones, anthraquinones (7), chlorogenic acid, dicaffeoylquinic acids, and ferulic acid (5). Kukongviriyapan et al (9) detected potent antioxidant activity in aqueous extracts of $\mathrm{CF}$ leaves. Other bioactivities demonstrated by CF include anti-inflammatory (10), antibacterial (11), antimicrobial (12) and anticancer (13). Various parts of the plant have been found to exert anticancer effects, including the roots, bark and leaves (14-16).

$\mathrm{CF}$ inhibits the proliferation of various types of cancer cell and induces cancer cell apoptosis. CF root extract has been reported to display activity against MCF-7 breast cancer cells, HeLa cervical cancer cells, HT-29 colon cancer cells, and $\mathrm{KB}$ oral cancer cells (6). CF leaf extract selectively inhibited human U937 leukemia cancer cells when compared with normal cells based on observations of DNA laddering and nuclear morphological changes (17). Nonpunya et al (18) and Senggunprai et al (19) showed that ethanolic CF leaf extracts inhibit cancer cell proliferation and induce apoptosis. CF selectively increased HepG2 liver cancer cell death when compared with normal cells by inducing caspase 3,8 and 9, decreasing the mitochondrial function and increasing apoptotic body formation (18). Consistent with the effects of $\mathrm{CF}$ on cholangiocarcinoma (CCA) cells, CF inhibited CCA cell proliferation, induced cell apoptosis, triggered cell cycle 
arrest at the $\mathrm{G}_{2} / \mathrm{M}$ phase, and downregulated cyclin $\mathrm{A}$ and cell division cycle 25A (CDC25A) protein expression levels (19). Furthermore, $\mathrm{CF}$ suppressed nuclear factor- $\mathrm{\kappa B}$ and signal transducer and activator of transcription 3 nuclear translocation and transcriptional activity, and inhibited cancer progression and metastasis (19).

Problems with increasing drug resistance and drug toxicity have stimulated investigation into novel anticancer compounds derived from natural sources, such as plants. As there is limited information on the effect of $\mathrm{CF}$ on liver cancer, the present study investigated the cytotoxicity and anti-migratory effects of $\mathrm{CF}$ extracts and their mechanisms of action on the human HepG2 liver cancer cell line. The results demonstrate that $\mathrm{CF}$ exerts potent anticancer activity, and this may provide a novel approach to liver cancer therapeutic strategies in future.

\section{Materials and methods}

Materials. Dulbecco's modified Eagle's medium (DMEM), fetal bovine serum (FBS) and the other cell culture reagents were purchased from Gibco (Thermo Fisher Scientific, Inc., Waltham, MA, USA). Protease inhibitor cocktail, dihydroethidium (DHE), RIPA lysis buffer, sulforhodamine B (SRB) and a caspase 3 activity assay kit were obtained from Sigma-Aldrich (Merck KGaA, Darmstadt, Germany). JC-1 was purchased from Cayman Chemical Company (Cayman Chemical Company, Ann Arbor, MI, USA). The primary antibodies against p21 $1^{\mathrm{Cip} / \mathrm{WAF} 1}$ (cat. no. 2947), cyclin D1 (cat. no. 2978), $\beta$-actin (cat. no. 4970), and anti-rabbit IgG horseradish peroxidase (HRP)-linked antibody (cat. no. 7074) antibody were purchased from Cell Signaling Technology, Inc. (Danvers, MA, USA). iScript reverse transcription Supermix for reverse transcription-quantitative polymerase chain reaction (RT-qPCR) and SsoFast EvaGreen Supermix were supplied by Bio-Rad Laboratories, Inc. (Hercules, CA, USA).

Plant material and extraction. Edible leaves of CF were collected from Udon Thani Province, Thailand, in May 2014. Identification was performed by the Pharmaceutical Laboratory Service Center, Faculty of Pharmaceutical Science, Prince of Songkla University (Hat Yai, Thailand; specimen no. SKP083030601) was deposited at the Prince of Songkla University Herbarium. Dried leaves were extracted using 50\% ethanol, filtered, evaporated and lyophilized to obtain the dry extract. The yield was $12.25 \%$ of the starting dry weight of the leaves. The $\mathrm{CF}$ leaf extract was maintained at $-20^{\circ} \mathrm{C}$ until use.

Cell lines and cell culture. The human HepG2 liver cancer cell line was obtained from the American Type Culture Collection (ATCC; Manassas, VA, USA) and maintained according to the recommendations of the ATCC at $37^{\circ} \mathrm{C}$ and $5 \% \mathrm{CO}_{2}$ in complete DMEM, supplemented with $100 \mathrm{U} / \mathrm{ml}$ penicillin $\mathrm{G}$, $100 \mu \mathrm{g} / \mathrm{ml}$ streptomycin and 10\% FBS. Subsequent to reaching confluence, the HepG2 cancer cells were detached using $0.25 \%$ trypsin-EDTA and $1 \times 10^{6}$ cells were seeded into the same complete medium. The DMEM medium was replaced every 3 days.

Cell viability assay. The SRB assay was used to determine the effect of CF on the viability of HepG2 cancer cells, as previously described (20). Briefly, cells were cultured in a 96-well plate for $24 \mathrm{~h}$ and fresh medium containing various concentrations of CF $(0-500 \mu \mathrm{g} / \mathrm{ml})$ were added. Subsequent to $24-48 \mathrm{~h}$, cells were fixed with ice-cold $10 \%$ trichloroacetic acid at $4{ }^{\circ} \mathrm{C}$, stained with $0.4 \% \mathrm{SRB}$ for $30 \mathrm{~min}$ at room temperature, and dissolved with $10 \mathrm{mM}$ Tris base solution. Absorbance was measured at a filter wavelength of $540 \mathrm{~nm}$ using a spectrophotometer (Opsys $\mathrm{MR}^{\mathrm{TM}}$ Microplate Reader; Dynex Technologies, Chantilly, VA, USA).

Clonogenic assay. The colony formation assay was used to determine the effect of $\mathrm{CF}$ on the cell regrowth of HepG2 cancer cells, as previously described (20). Briefly, 500 viable HepG2 cancer cells were seeded in 6-well plates (500 cells/well) for $24 \mathrm{~h}$, treated with various concentrations of CF $(0-200 \mu \mathrm{g} / \mathrm{ml})$ for $24 \mathrm{~h}$, washed once with phosphate-buffered saline (PBS) and resuspended in fresh medium. HepG2 cells were grown for another 24 days. Subsequently, the DMEM medium was discarded, the cells were washed with PBS buffer three times, fixed with $100 \%$ methanol at $-20^{\circ} \mathrm{C}$, stained with $0.5 \%$ crystal violet in $100 \%$ methanol for $1 \mathrm{~h}$ at room temperature, washed with tap water, and the colonies were viewed and captured using a digital camera (Nikon D3100). Colonies containing $>50$ individual cells were counted using Image-Pro Plus software (Media Cybernetics, L.P., Silver Spring, MA, USA).

Wound healing assay. Cell migration was assessed using a wound healing assay, as previously described (20). Briefly, HepG2 cancer cells were seeded into 24-well plates for $24 \mathrm{~h}$. Cells were scratched using a sterile 0.2 -ml pipette tip, certain cells were untreated and others were treated with different concentrations of CF $(0-100 \mu \mathrm{g} / \mathrm{ml})$. Images were obtained from 0 to $48 \mathrm{~h}$. The closing of the scratched wound was determined by image capture of the uncovered area along the scratch. The wound distance was calculated by dividing the area by the length of the scratch, and this was compared with the untreated control group. Cell migration was monitored by phase contrast microscopy (Nikon Eclipse TS100 inverted microscope; magnification, x10).

Reactive oxygen species (ROS) production assay. Intracellular ROS generation was measured using DHE, the cell-permeable fluorescent probe. Briefly, HepG2 cancer cells were seeded and cultured in black 96-well plates for $24 \mathrm{~h}$. The cells were treated with CF $(0-250 \mu \mathrm{g} / \mathrm{ml})$ plus $25 \mu \mathrm{M}$ DHE in serum-free medium and maintained at $37^{\circ} \mathrm{C}$ for $90 \mathrm{~min}$ in a $5 \% \mathrm{CO}_{2}$ incubator in the dark. The fluorescence intensity was measured on a fluorescence microplate reader at $518 \mathrm{~nm}$ (excitation) and $605 \mathrm{~nm}$ (emission). Data were expressed as the percentage of ROS relative to untreated control groups.

Caspase 3 activity assay. Caspase 3 activity was measured using caspase 3 fluorimetric assay kits according to the manufacturer's instructions. Briefly, HepG2 cancer cells were treated with $\mathrm{CF}(0-100 \mu \mathrm{g} / \mathrm{ml})$ for $24 \mathrm{~h}$, lysed, and the protein concentrations were measured using Bradford's reagent (Bio-Rad Laboratories, Inc.). The caspase 3 activity reactions were composed of cell lysates and buffer containing the caspase 3 substrate, acetyl Asp-Glu-Val-Asp 7-amido-4-methylcoumarin 
Table I. Polymerase chain reaction primer sequences.

Primers

\begin{tabular}{lll}
\cline { 2 - 3 } Gene & \multicolumn{1}{c}{ Forward } & Reverse \\
\hline$R A C 1$ & 5'ATG-TCC-GTG-CAA-AGT-GGT-ATC3' & 5'CTC-GGA-TCG-CTT-CGT-CAA-ACA3' \\
$C D K 6$ & 5'GCT-GAC-CAG-CAG-TAC-GAA-TG3' & 5'GCA-CAC-ATC-AAA-CAA-CCT-GAC-C3' \\
$A C T B$ & 5'CAT-GTA-CGT-TGC-TAT-CCA-GGC3' & 5'CTC-CTT-AAT-GTC-ACG-CAC-GAT3' \\
\hline
\end{tabular}

RAC1, ras-related C3 botulinum toxin substrate 1 (rho family, small GTP binding protein Rac1); CDK6, cyclin dependent kinase 6; ACTB, $\beta$-actin

(AMC; Santa Cruz Biotechnology, Inc., Dallas, TX, USA). These mixtures were incubated at $37^{\circ} \mathrm{C}$ in the dark for $90 \mathrm{~min}$. The AMC fluorescence intensity was read using a fluorescence plate reader at $360 \mathrm{~nm}$ (excitation) and $460 \mathrm{~nm}$ (emission). AMC served as a standard to calculate the caspase 3 activity.

Measurement of mitochondrial membrane potentiall $(\Delta \Psi m)$. JC-1, the lipophilic cationic fluorescent dye, was used to measure changes in $\Delta \Psi \mathrm{m}$. Briefly, HepG2 cancer cells were seeded into black 96-well plates for $24 \mathrm{~h}$, treated with $\mathrm{CF}$ $(0-100 \mu \mathrm{g} / \mathrm{ml})$ for $24 \mathrm{~h}$, loaded with $\mathrm{JC}-1$, and incubated for $30 \mathrm{~min}$ at $37^{\circ} \mathrm{C}$ in the dark. Subsequently, the cells were rinsed with PBS buffer and added $200 \mu \mathrm{JC} 1$ assay buffer and then read the fluorescent intensity. The $\Delta \Psi$ m was measured using a fluorescence plate reader at $485 \mathrm{~nm}$ (excitation) and $535 \mathrm{~nm}$ (emission). In normal cells, JC-1 transforms to J-aggregate and in dead cells, JC-1 exists in monomeric form. The fluorescence intensity ratio of J-aggregates to JC-1 monomers served as an indicator of the depolarization of $\Delta \Psi \mathrm{m}$.

Gelatin zymography analysis. The expression levels of matrix metalloproteinase-9 (the MMP-9) in conditioned medium were detected by gelatin zymography. Briefly, HepG2 cancer cells were seeded in 24-well culture plates for $24 \mathrm{~h}$. Subsequently, HepG2 cancer cells were cultured in complete DMEM medium containing different concentrations of CF $(0-100 \mu \mathrm{g} / \mathrm{ml})$ at $37^{\circ} \mathrm{C}$ for $48 \mathrm{~h}$. The culture medium was then collected, centrifuged at $400 \times \mathrm{g}$ for $5 \mathrm{~min}$ at $4^{\circ} \mathrm{C}$, and the protein concentration was measured using Bradford's reagent. The protein samples were combined with $2 \mathrm{X}$ non-reducing sample buffer without heating, loaded onto a 10\% SDS-polyacrylamide gel (Bio-Rad Laboratories, Inc.) containing $0.1 \%$ (w/v) gelatin and subjected to electrophoresis at $120 \mathrm{~V}$ for $1.5 \mathrm{~h}$. Following electrophoresis, the gel was washed three times with $2.5 \%$ Triton $\mathrm{X}-100$ to remove the SDS and incubated with developing buffer [50 $\mathrm{mM}$ Tris- $\mathrm{HCl}$ buffer ( $\mathrm{pH} \mathrm{7.45)}$ and $10 \mathrm{mM} \mathrm{CaCl}_{2}$ ] at $37^{\circ} \mathrm{C}$ for $12 \mathrm{~h}$. The gels were stained with $0.1 \%$ Coomassie Brilliant Blue $\mathrm{R}-250$ for $1 \mathrm{~h}$ at room temperature and washed with destaining solution until clear bands were observable against an intensely stained background.

Gene expression assay. Briefly, the HepG2 cancer cells were seeded in 6-well plates for $24 \mathrm{~h}$ and treated with CF for $24 \mathrm{~h}$. RNA was isolated and cDNA was prepared. PCR amplification was performed using specific primers for ras-related $\mathrm{C} 3$ botulinum toxin substrate 1 (rho family, small GTP binding protein Rac1) (RAC1) and cyclin dependent kinase 6 (CDK6), and ACTB served as an internal control. The PCR primer sequences are presented in Table I.

RT-qPCR was performed in a final reaction volume of $20 \mu \mathrm{l}$ containing SYBR-Green PCR Master Mix, the target gene and the internal control, ACTB under the following conditions: Denaturation at $95^{\circ} \mathrm{C}$ for $3 \mathrm{~min}$; amplification (40 cycles) at $95^{\circ} \mathrm{C}$ for $15 \mathrm{sec}$ and $60^{\circ} \mathrm{C}$ for $30 \mathrm{sec}$. Expression of each gene was monitored using an Applied Biosystems ${ }^{\circledR}$ StepOne $^{\mathrm{TM}}$ real-time PCR system (Thermo Fisher Scientific, Inc.). Differences in gene expression levels were calculated using the $2^{-\Delta \Delta \mathrm{Cq}}$ method for relative quantification, and expressed as the fold change relative to the untreated control (21).

Protein extraction and western blot analysis. Briefly, HepG2 cells were treated with $100 \mu \mathrm{g} / \mathrm{ml} \mathrm{CF}$ for $24 \mathrm{~h}$, lysed with RIPA lysis buffer and centrifuged at $10,000 \times \mathrm{g}$ at $4^{\circ} \mathrm{C}$ for $30 \mathrm{~min}$. The supernatant was collected and the protein concentration was determined. A sample of $20 \mu \mathrm{g}$ total protein was then separated by $12 \%$ SDS-polyacrylamide gel electrophoresis $(120 \mathrm{~V}$ for $1.5 \mathrm{~h}$ ) and transferred to PVDF membranes (Immobilon ${ }^{\circledR}$; EMD Millipore, Billerica, MA, USA). The membranes were incubated with each primary antibody (p21 ${ }^{\mathrm{Cip} / \mathrm{WAF} 1}$, cyclin D1 and $\mathrm{ACTB}$ ), at a dilution of 1:2,500, overnight and with the HRP-conjugated secondary antibody (dilution, 1:5,000) for $2 \mathrm{~h}$. Bands were detected using an enhanced Clarity ${ }^{\mathrm{TM}}$ Western ECL Substrate (Bio-Rad Laboratories, Inc.).

Statistical analysis. Statistical comparison of the control and CF groups was performed using Student's t-test and one-way analysis of variance, followed by Tukey's post-hoc test. The analyses were conducted using SigmaStat software version 3.5 (Systat Software Inc., San Jose, CA, USA) and values are expressed as the mean \pm standard error of the mean of three determinations. $\mathrm{P}<0.05$ was considered to indicate a statistically significant difference.

\section{Results}

Effects of CF on cytotoxicity and colony formation efficacy in HepG2 liver cancer cells. To assess the cytotoxicity of $\mathrm{CF}$ on human HepG2 liver cells, the cells were cultured with various concentrations of $\mathrm{CF}$ for 24-48 h and the cytotoxicity was determined using the SRB assay (Fig. 1A). The results 


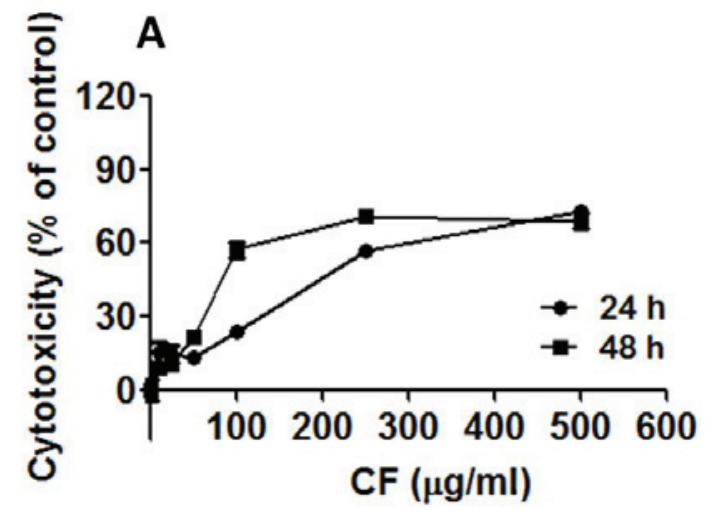

B

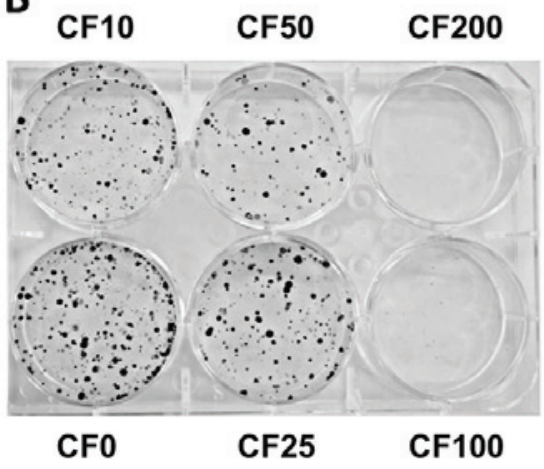

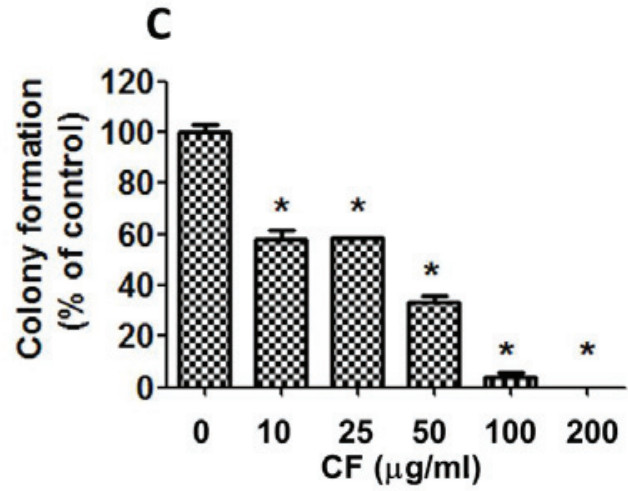

Figure 1. Effect of CF on HepG2 cell death and cell regrowth. (A) HepG2 cancer cells were treated with various concentrations of CF (0-500 $\mu$ g/ml) for 24 and $48 \mathrm{~h}$. Cell death was determined using an SRB assay. (B and C) Cells were treated with various concentrations of CF (0-200 $\mu \mathrm{g} / \mathrm{ml})$ for $24 \mathrm{~h}$. Subsequently, the cells were cultured for 24 days and examined via clonogenic assay. The results are presented as the percentage of the untreated control groups $(0 \mu \mathrm{g} / \mathrm{ml})$, and represent means \pm standard error of the mean from three independent experiments. ${ }^{*} \mathrm{P}<0.05$ vs. untreated control groups $(0 \mu \mathrm{g} / \mathrm{ml})$. CF, Cratoxy formosum.

indicate that cell growth was strongly inhibited in a doseand time-dependent manner with half maximal inhibitory concentration $\left(\mathrm{IC}_{50}\right)$ values of $219.03 \pm 9.96 \mu \mathrm{g} / \mathrm{ml}$ at $24 \mathrm{~h}$ and $124.90 \pm 6.86 \mu \mathrm{g} / \mathrm{ml}$ at $48 \mathrm{~h}$ (Fig. $1 \mathrm{~A})$.

To determine the effect of $\mathrm{CF}$ on the replicative potential and longer term viability of HepG2 cells, a colony formation assay was used. CF caused a dose-dependent decline in the colony forming ability of HepG2 cells with $\mathrm{IC}_{50}$ values of $20.06 \pm 1.52 \mu \mathrm{g} / \mathrm{ml}$ (Fig. 1B and C). CF inhibited cell regrowth at a lower concentration when compared with the CF concentration that induces cancer cell death. CF exhibited cytotoxic and antiproliferative effects against the HepG2 liver cancer cells.

Effects of CF on liver cancer cell migration. To determine whether CF inhibits cancer cell migration, a wound healing assay was performed. The results demonstrate that CF significantly inhibited cancer cell migration in a dose-dependent manner. At a concentration of $100 \mu \mathrm{g} / \mathrm{ml}, \mathrm{CF}$ inhibited HepG2 cancer cell migration by $\sim 40 \%$ when compared with the untreated control group (Fig. 2A and B).

The effects of CF on the expression of invasion-linked matrix metalloproteinase-9 (MMP-9) were then assessed. The expression level of MMP-9 was relatively high in the HepG2 cancer cells in the untreated control group. CF treatment suppressed MMP-9 in a dose-dependent manner, and significantly decreased MMP-9 at a concentration of $100 \mu \mathrm{g} / \mathrm{ml}$ when compared with the untreated control group (Fig. 2C and D).

Effects of CF on ROS formation, caspase 3 activity and $\Delta \Psi m$ in HepG2 liver cancer cells. To establish the mechanism by which CF causes cancer cell death, the intracellular accumulation of ROS was examined using a DHE-enhanced fluorescent probe. Upon treatment of the HepG2 cancer cells with $\mathrm{CF}$, ROS were released in a dose-dependent manner (Fig. 3A). CF induced the production of ROS in a dose-dependent manner when compared with the untreated control group $(\mathrm{P}<0.05)$.

In addition, the involvement of mitochondria in $\mathrm{CF}$-induced cytotoxicity was determined. The function of mitochondria was investigated by measuring caspase 3 activities, and mitochondrial dysfunction using the fluorescent dye JC-1. The results indicated that $\mathrm{CF}$ treatment activates caspase 3 activities in a dose-dependent manner (Fig. 3B). Furthermore, CF depolarized the $\Delta \Psi \mathrm{m}$, as shown by the decline in the JC-1 aggregates/JC-1 monomers ratio. The lowest concentration at which the decrease in $\Delta \Psi \mathrm{m}$ was significant was $50 \mu \mathrm{g} / \mathrm{ml}$ (Fig. 3C).

Effects of CF on RACl and downstream gene expression, and protein-associated apoptosis. Whether CF inhibits mRNA expression of the cell cycle regulator, RACl and the 
A

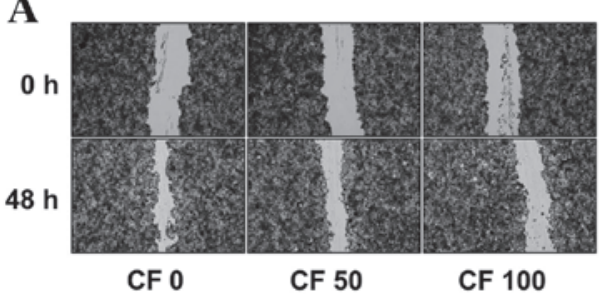

C

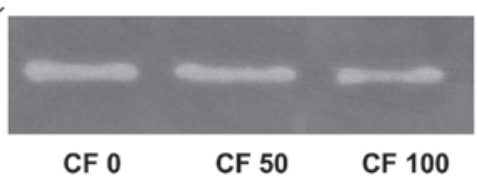

B

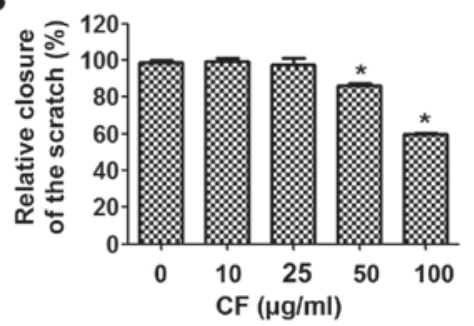

D

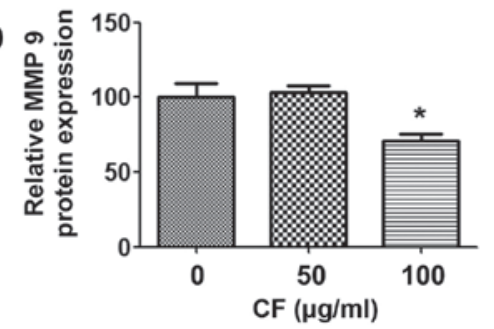

Figure 2. Effects of CF on HepG2 cell migration and MMP-9 protein expression levels. (A) Wound healing assays were performed on HepG2 cells that had been treated with various concentrations $(0-100 \mu \mathrm{g} / \mathrm{ml})$ of $\mathrm{CF}$ for $48 \mathrm{~h}$. Cell migration was monitored by phase contrast microscopy (magnification, $\mathrm{x} 10)$. (B) The bar chart presents the level of cell migration into the wound scratch quantified as a percentage of wound closure at $48 \mathrm{~h}$. (C) The effects of $\mathrm{CF}$ $(0-100 \mu \mathrm{g} / \mathrm{ml})$ on MMP 9 expression levels in conditioned media were analyzed by gelatin zymography. (D) The bar chart demonstrates the relative expression of MMP-9 in HepG2 cancer cells. The data are presented as means \pm standard error of the mean from three independent experiments. ${ }^{*}<0.05$ vs. untreated control groups $(0 \mu \mathrm{g} / \mathrm{ml})$. CF, Cratoxy formosum; MMP-9, matrix metalloproteinase-9.
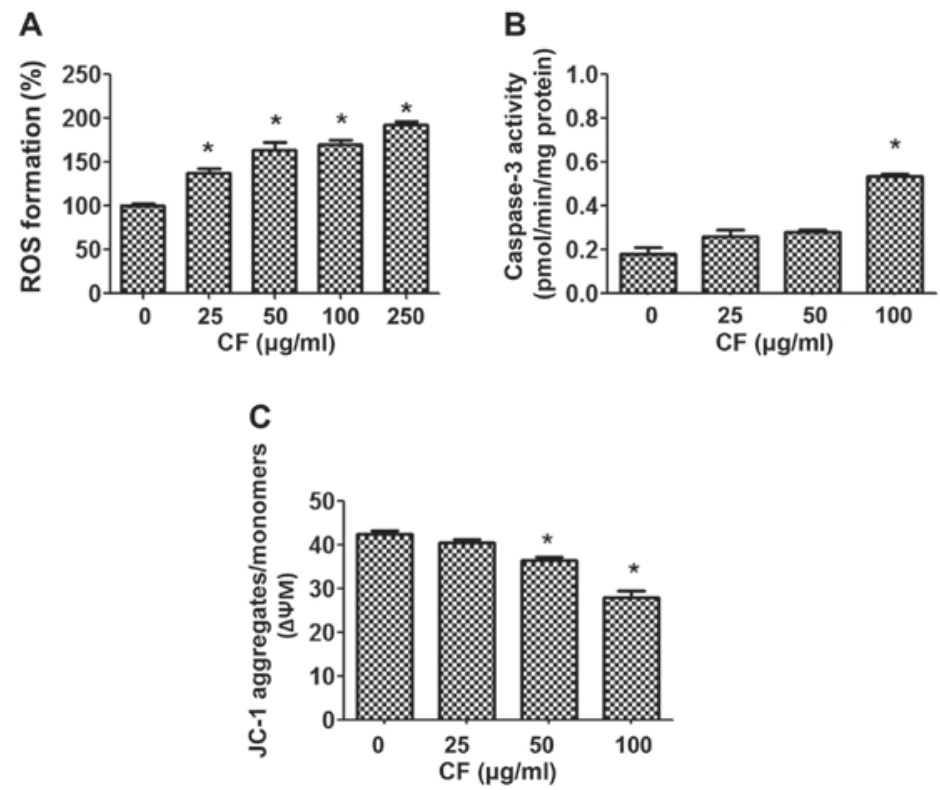

Figure 3. Effect of CF on (A) ROS production, (B) caspase 3 activity and (C) $\Delta \Psi \mathrm{m}$. HepG2 cells were incubated with various concentrations of CF $(0-250 \mu \mathrm{g} / \mathrm{ml})$. ROS formation was quantified using a dihydroethidium-enhanced fluorescent probe. Cells were treated with CF $(0-100 \mu \mathrm{g} / \mathrm{ml})$ for $24 \mathrm{~h}$ and caspase 3 activity was determined via caspase 3 assay. The $\Delta \Psi \mathrm{m}$ was determined by incubating cells with the fluorescent dye JC-1 and $\Delta \Psi \mathrm{m}$ was assessed using the ratio of fluorescence intensity of JC-1 aggregates/JC-1 monomers. Each bar represents the mean \pm standard error the mean of three experiments. ${ }^{*} \mathrm{P}<0.05$ vs. untreated control groups $(0 \mu \mathrm{g} / \mathrm{ml})$. CF, Cratoxy formosum; ROS, reactive oxygen species; $\Delta \Psi \mathrm{m}$, mitochondrial transmembrane potential.

downstream gene, $C D K 6$ was investigated. $\mathrm{CF}$ did not alter the expression levels of either of these genes in the HepG2 cells (Fig. 4A and B). Proteins, p21 and cyclin D1, which are associated with cell survival, were examined by western blot analysis to determine whether CF inhibits HepG2 cell proliferation. The results indicated that $\mathrm{CF}$ significantly induces p21 expression to inhibit the cell cycle, which is correlated with a reduction in cyclin D1 protein expression in HepG2 cells (Fig. 4C-E). The present results found that $\mathrm{CF}$ causes HepG2 cancer cell death by stimulating the cell cycle protein inhibitor, p21, and reducing expression levels of the cell cycle protein, cyclin D1.

\section{Discussion}

In the present study, the mechanism by which $\mathrm{CF}$ reduces cell proliferation, decreases cell migration, and enhances cell death was investigated in the human HepG2 liver cancer cell line. The results demonstrate that $\mathrm{CF}$-induced cancer cell death may be due to induction of intracellular ROS, leading 
A

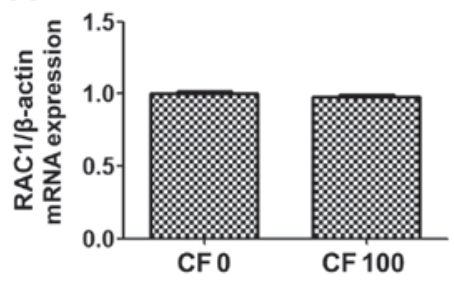

B

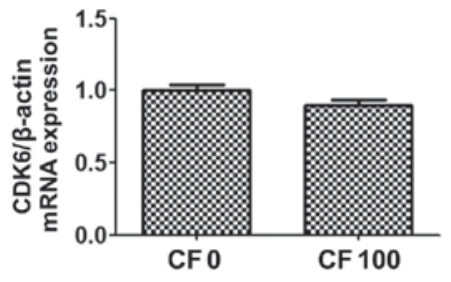

C

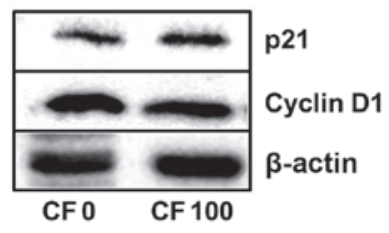

D

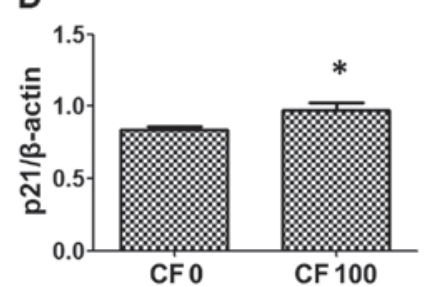

E

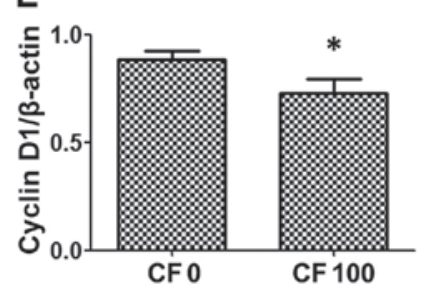

Figure 4. Effects of CF on expression levels of (A) RAC1 and (B) CDK6 and (C-E) protein expression of p21 and cyclin D1 in HepG2 cells. Cells were treated with $100 \mu \mathrm{g} / \mathrm{ml} \mathrm{CF}$ for $24 \mathrm{~h}$. Total RNA was analyzed by quantitative polymerase chain reaction. The mRNA expression of targeted genes was normalized against ACTB (the control). Effects of CF on p21 and cyclin D1 protein expression were also determined. Cells were treated with $100 \mu \mathrm{g} / \mathrm{ml} \mathrm{CF}$ for $24 \mathrm{~h}$. Whole cells were lysed, prepared, and subjected to western blot analysis. The expression levels of p21 and cyclin D1 protein were normalized against ACTB (the control). The bars indicate the mean \pm standard error of the mean, each from three independent experiments. ${ }^{*} \mathrm{P}<0.05 \mathrm{vs}$. untreated control groups $(0 \mu \mathrm{g} / \mathrm{ml})$. CF, Cratoxy formosum; RAC1, ras-related C3 botulinum toxin substrate 1 (rho family, small GTP binding protein Rac1); CDK6, cyclin dependent kinase 6; ACTB, $\beta$-actin.

to altered mitochondrial function and increased caspase 3 activity. In addition, CF increased p21 expression levels and decreased cyclin D1 protein expression levels. CF also inhibited migration by decreasing the level of MMP-9 protein expression. This may represent the mechanism of cancer cell sensitization and killing. Hence, CF may yield compounds of potential use in the prevention and treatment of liver cancer.

Cancer is uninhibited cell growth, accelerated angiogenesis, and stimulated invasion and metastasis (22). Mutations in genes cause cancer by accelerating cell division or inhibiting normal controls on the system, such as cell cycle arrest or programmed cell death (22). Accordingly, two of the necessary activities of an anticancer compound are to interrupt the uncontrolled cell proliferation and accelerate cell death of cancer cells (23). Medicinal herbs and dietary plants are a popular starting point for anticancer drug development. In the current study, low concentrations of CF exerted a marked effect on the induction of liver cancer cell death and inhibition of colony formation. CF appeared to inhibit the growth of HepG2 cancer cells. Previous in vitro studies revealed that $\mathrm{CF}$ inhibits growth and induces apoptosis in numerous types of cancer cell, including liver (18), oral (24), bile duct (19) and cervical (25). Senggunprai et al (19) demonstrated that CF was potently cytotoxic against CCA KKU-M156 cells, induced cell apoptosis and inhibited colony formation.

To elucidate the underlying mechanism of cell growth inhibition, cell cycle distribution was evaluated using $R A C 1$ and $C D K 6$ gene expression, and cell cycle-associated proteins, p21 and cyclin D1; their expression levels were measured in HepG2 cancer cells. The results indicated that $\mathrm{CF}$ did not alter RAC1 or CDK6 expression levels in the HepG2 cells. Conversely, CF extracts induced p21 expression and downregulated cyclin D1 protein expression. p21 is a cyclin-dependent kinase inhibitor protein essential for inhibiting cellular growth and inducing apoptosis (26). Cyclin D1 binds and activates CDK6, and thus promotes cell cycle $\mathrm{G}_{1} / \mathrm{S}$ transitions (27). The current results indicated that $\mathrm{CF}$ activates cancer cell death or inhibits cancer cell proliferation by increasing p21 protein expression and inhibiting cylin D1 protein expression. Similarly, CF extracts have been shown to induce cell cycle arrest in CCA cells at the $\mathrm{G}_{2} / \mathrm{M}$ phase, and downregulate cyclin A and CDC25A protein expression (19). These results indicate that $\mathrm{CF}$ exerts potent activity against human HepG2 cancer cells.

Various studies have screened for compounds that trigger apoptosis by measuring caspase activity and mitochondrial membrane potential (28). Caspase enzymes are proteases that are used to determine whether apoptosis is being triggered via the intrinsic or extrinsic pathway (29). Caspase 3 activity is the final step in the two pathways. Results from the present study indicate that $\mathrm{CF}$ induces the late stages of apoptosis because an increase in caspase 3 activity and a decrease in $\Delta \Psi \mathrm{m}$ were observed in the HepG2 cancer cells. The present results demonstrate that $\mathrm{CF}$ induces liver cancer cell apoptosis. ROS are generated by cellular oxidative processes and trigger different cellular responses, such as cell cycle arrest, apoptosis or necrosis, depending on the intensity of the oxidative damage (30). Previous results have shown that CF exerts antioxidant activity, allowing it to suppress inflammation and act as a chemopreventive agent. The current results demonstrate that high concentrations of CF cause ROS formation in HepG2 cancer cells. Therefore the method by which CF induces ROS formation in cancer cells was examined in the current study.

Metastasis is the process by which a tumor cell leaves the primary tumor, travels to a distant site via the circulatory system, and establishes a secondary tumor. Such metastases are the cause of the majority of cancer-associated mortalities $(31,32)$. The process involves a cascade of events, including cell adhesion, degradation of the extracellular matrix, cell movement, cell motility and invasion (33). A 
compound with the ability to block the metastasis-associated signaling pathway may be a potential candidate for chemotherapy. It has been reported that activation of the Rho family GTPase, RAC1 is a critical event in the integrin- and growth factor-mediated regulation of cellular migration and adhesion, implicating the hyperactivation of these proteins in the progression of metastatic disease (34). The current study found that $\mathrm{CF}$ did not alter $R A C l$ expression, and may therefore regulate other genes and proteins. Protein MMP-9 is crucial in tumor invasion and metastasis. Thus, it was hypothesized that CF may reduce the ability of HepG2 cancer cells to migrate and invade by decreasing the expression level of MMP-9. In the present study, treatment with CF decreased cancer cell migration in HepG2 cancer cells. It should be noted that the anti-migratory effect of CF was detected at lower concentrations than the concentrations that inhibited cell growth. These results indicate that $\mathrm{CF}$ suppresses the metastatic potential of cancer cells, at least in part, by modulating the MMP-9 signaling pathway.

$\mathrm{CF}$ accelerates liver cancer cell death and reduces cancer cell migration, however, the active compounds in this crude extract have yet to be identified. It has been previously reported that $\mathrm{CF}$ has a high content of phenolic acids and flavonoids. These compounds are widely distributed in plants, exert antioxidant effects, and possess the potential to reduce the risk of cancer $(9,13)$. Various phenolic acids and flavonoids were identified in the extracts, with myricetin, syringic acid, and luteolin identified as the main components (19). Further studies are required to isolate and identify the compound(s) contributing to the anticancer properties of the CF extract.

In conclusion, $\mathrm{CF}$ leaf extract exerts cytotoxic activity against the HepG2 liver cancer cell line in in vitro assays. Furthermore, CF induced apoptosis, in part, by inhibiting proliferation. CF represents a potentially important anticancer agent, inhibiting cancer cell proliferation and inducing cancer cell death by enhancing p21 protein expression levels, blocking the cell cycle-associated protein, cyclin D1, and inducing the apoptotic cell death pathway. Additionally, CF inhibits migration of HepG2 cancer cells by reducing MMP-9 protein expression levels. Additional studies are required to characterize the effects of the crude CF extract on other cancer cell lines and to isolate the phytoconstituents responsible for these effects. Further in vivo investigation of the mechanism(s) of action and toxicity are also required before this medicinal plant or its constituents become a novel option for the treatment of liver cancer.

\section{Acknowledgements}

The present study was financially supported by the Office of the Higher Education Commission (grant no. 2559A10962004), the Office of Thai Traditional Medical Knowledge Fund, a Mahasarakham University 2016 Thailand Research Fund (grant no. TRG5780254), and the National Research Council of Thailand (grant no. 2559A10902073). The authors thank Dr. Tim Cushnie (MSU Faculty of Medicine) for language editing of the manuscript. The authors acknowledge Mahasarakham University Faculty of Science (Maha Sarakham, Thailand) for equipment support and laboratory space.

\section{References}

1. Cragg GM and Newman DJ: Plants as a source of anti-cancer agents. J Ethnopharmacol 100: 72-79, 2005.

2. Pereira A and Maraschin M: Banana (Musa spp) from peel to pulp: Ethnopharmacology, source of bioactive compounds and its relevance for human health. J Ethnopharmacol 160: 149-163, 2015.

3. Rozza AL and Pellizzon CH: Essential oils from medicinal and aromatic plants: A review of the gastroprotective and ulcer-healing activities. Fundam Clin Pharmacol 27: 51-63, 2013.

4. Sucher NJ and Carles MC: A pharmacological basis of herbal medicines for epilepsy. Epilepsy Behav 52: 308-318, 2015.

5. Maisuthisakul P, Pongsawatmanit $\mathrm{R}$ and Gordon $\mathrm{MH}$ : Antioxidant properties of Teaw (Cratoxylum formosum Dyer) extract in soybean oil and emulsions. J Agric Food Chem 54: 2719-2725, 2006.

6. Boonnak N KC, Chantrapromma S, Ponglimanont C, Fun HK, Kanjana- and Opas A LS: Bioactive prenylated xanthones and anthraquinones from Cratoxylum formosum ssp. Pruniflorum. Tetrahedron 64: 10, 2006.

7. Duan YH, Dai Y, Wang GH, Zhang X, Chen HF, Chen JB, Yao XS and Zhang XK: Bioactive xanthones from the stems of Cratoxylum formosum ssp. Pruniflorum. J Nat Prod 73: 1283-1287, 2010.

8. Maisuthisakul P and Gordon $\mathrm{MH}$ : Characterization and storage stability of the extract of Thai mango (Mangifera indica Linn. Cultivar Chok-Anan) seed kernels. J Food Sci Technol 51: 1453-1462, 2014.

9. Kukongviriyapan U, Luangaram S, Leekhaosoong K, Kukongviriyapan V and Preeprame S: Antioxidant and vascular protective activities of Cratoxylum formosum, Syzygium gratum and Limnophila aromatica. Biol Pharm Bull 30: 661-666, 2007.

10. Sripanidkulchai K, Teepsawang S and Sripanidkulchai B: Protective effect of Cratoxylum formosum extract against acid/alcohol-induced gastric mucosal damage in rats. J Med Food 13: 1097-1103, 2010.

11. Raksat A, Laphookhieo S, Cheenpracha S, Ritthiwigrom T and Maneerat W: Antibacterial compounds from the roots of Cratoxylum formosum spp. Pruniflorum. Nat Prod Commun 9: 1487-1489, 2014.

12. Suddhasthira T, Thaweboon S, Dendoung N, Thaweboon B and Dechkunakorn S: Antimicrobial activity of Cratoxylum formosum on Streptococcus mutans. Southeast Asian J Trop Med Public Health 37: 1156-1159, 2006.

13. Waiyaput W, Payungporn S, Issara-Amphorn J and Panjaworayan NT: Inhibitory effects of crude extracts from some edible Thai plants against replication of hepatitis B virus and human liver cancer cells. BMC Complement Altern Med 12: 246, 2012.

14. Kowsalya R, Kaliaperumal J, Vaishnavi M and Namasivayam E: Anticancer activity of Cynodon dactylon L. Root extract against diethyl nitrosamine induced hepatic carcinoma. South Asian J Cancer 4: 83-87, 2015.

15. Moore J, Yousef M and Tsiani E: Anticancer effects of rosemary (Rosmarinus officinalis L.) Extract and rosemary extract polyphenols. Nutrients 8: pii:E731, 2016.

16. Nair SV, Hettihewa M and Rupasinghe HP: Apoptotic and inhibitory effects on cell proliferation of hepatocellular carcinoma HepG2 cells by methanol leaf extract of Costus speciosus. Biomed Res Int 2014: 637098, 2014.

17. Machana S, Weerapreeyakul N, Barusrux S, Thumanu K and Tanthanuch W: FTIR microspectroscopy discriminates anticancer action on human leukemic cells by extracts of Pinus kesiya; Cratoxylum formosum ssp. Pruniflorum and melphalan. Talanta 93: 371-382, 2012.

18. Nonpunya A, Weerapreeyakul $\mathrm{N}$ and Barusrux S: Cratoxylum formosum (Jack) Dyer ssp. Pruniflorum (Kurz) Gogel. (Hóng yá mù) extract induces apoptosis in human hepatocellular carcinoma HepG2 cells through caspase-dependent pathways. Chin Med 9: 12, 2014.

19. Senggunprai L, Thammaniwit W, Kukongviriyapan V, Prawan A, Kaewseejan N and Siriamornpun S: Cratoxylum formosum extracts inhibit growth and metastasis of cholangiocarcinoma cells by modulating the NF-kB and STAT3 pathways. Nutr Cancer 68: 328-341, 2016.

20. Buranrat B, Senggunprai L, Prawan A and Kukongviriyapan V: Simvastatin and atorvastatin as inhibitors of proliferation and inducers of apoptosis in human cholangiocarcinoma cells. Life Sci 153: 41-49, 2016. 
21. Livak KJ and Schmittgen TD: Analysis of relative gene expression data using real-time quantitative PCR and the 2(-Delta Delta C(T)) Method. Methods 25: 402-408, 2001.

22. Hassan M, Watari H, AbuAlmaaty A, Ohba Y and Sakuragi N: Apoptosis and molecular targeting therapy in cancer. Biomed Res Int 2014: 150845, 2014.

23. Schwartz GK and Shah MA: Targeting the cell cycle: A new approach to cancer therapy. J Clin Oncol 23: 9408-9421, 2005.

24. Promraksa B, Daduang J, Chaiyarit P, Tavichakorntrakool R, Khampitak T, Rattanata N, Tangrassameeprasert $\mathrm{R}$ and Boonsiri P: Cytotoxicity of cratoxylum formosum subsp. Pruniflorum Gogel extracts in oral cancer cell lines. Asian Pac J Cancer Prev 16: 7155-7159, 2015.

25. Promraksa B, Daduang J, Khampitak T, Tavichakorntrakool R, Koraneekit A, Palasap A, Tangrassameeprasert R and Boonsiri P: Anticancer potential of cratoxylum formosum subsp. Pruniflorum (Kurz.) Gogel extracts against cervical cancer cell lines. Asian Pac J Cancer Prev 16: 6117-6121, 2015.

26. Xiong Y, Hannon GJ, Zhang H, Casso D, Kobayashi R and Beach D: p21 is a universal inhibitor of cyclin kinases. Nature 366: 701-704, 1993.

27. Vermeulen K, Van Bockstaele DR and Berneman ZN: The cell cycle: A review of regulation, deregulation and therapeutic targets in cancer. Cell Prolif 36: 131-149, 2003.

28. Koceva-Chyła A, Jedrzejczak M, Skierski J, Kania K and Jóźwiak Z: Mechanisms of induction of apoptosis by anthraquinone anticancer drugs aclarubicin and mitoxantrone in comparison with doxorubicin: Relation to drug cytotoxicity and caspase-3 activation. Apoptosis 10: 1497-1514, 2005.
29. Liu MJ, Wang Z, Li HX, Wu RC, Liu YZ and Wu QY: Mitochondrial dysfunction as an early event in the process of apoptosis induced by woodfordin I in human leukemia K562 cells. Toxicol Appl Pharmacol 194: 141-155, 2004.

30. Barzilai A and Yamamoto K: DNA damage responses to oxidative stress. DNA Repair (Amst) 3: 1109-1115, 2004.

31. Chambers AF, Groom AC and MacDonald IC: Dissemination and growth of cancer cells in metastatic sites. Nat Rev Cancer 2: 563-572, 2002

32. Gupta GP and Massagué J: Cancer metastasis: Building a framework. Cell 127: 679-695, 2006.

33. Morrissey MA, Hagedorn EJ and Sherwood DR: Cell invasion through basement membrane: The netrin receptor DCC guides the way. Worm 2: e26169, 2013.

34. Ridley AJ, Schwartz MA, Burridge K, Firtel RA, Ginsberg MH, Borisy G, Parsons JT and Horwitz AR: Cell migration: Integrating signals from front to back. Science 302: 1704-1709, 2003. 